\title{
Adult AMPA GLUAI Receptor Subunit Loss in 5-HT Neurons Results in a Specific Anxiety-Phenotype with Evidence for Dysregulation of 5-HT Neuronal Activity
}

\author{
Tillmann Weber*, 1,2,8, Miriam A Vogt ${ }^{3,8}$, Sarah E Gartside ${ }^{4}$, Stefan M Berger ${ }^{2}$, Rafael Lujan ${ }^{5}$, Thorsten Lau ${ }^{6}$, \\ Elke Herrmann ${ }^{2}$, Rolf Sprengel ${ }^{7}$, Dusan Bartsch ${ }^{2,8}$ and Peter Gass ${ }^{3,8}$ \\ 'Department of Addictive Behavior and Addiction Medicine, Central Institute of Mental Health, Medical Faculty Mannheim/Heidelberg \\ University, Mannheim, Germany; ${ }^{2}$ Department of Molecular Biology, Central Institute of Mental Health, Medical Faculty Mannheim/Heidelberg \\ University, Mannheim, Germany; ${ }^{3}$ Research Group Animal Models in Psychiatry, Department of Psychiatry and Psychotherapy, Central Institute of \\ Mental Health, Medical Faculty Mannheim/Heidelberg University, Mannheim, Germany; ${ }^{4}$ Institute of Neuroscience, The Medical School, \\ Newcastle University, Newcastle upon Tyne, UK: Instituto de Investigación en Discapacidades Neurológicas (IDINE), Departamento de Ciencias \\ Médicas, Facultad de Medicina, Universidad Castilla-La Mancha, Campus Biosanitario, Albacete, Spain; ${ }^{6}$ Biochemical Laboratory, Department of \\ Psychiatry and Psychotherapy, Central Institute of Mental Health, Medical Faculty Mannheim/HeidelbergUniversity, Mannheim, Germany; \\ ${ }^{7}$ Department of Molecular Neurobiology, Max Planck Institute for Medical Research, Heidelberg, Germany
}

\begin{abstract}
Both the glutamatergic and serotonergic $(5-\mathrm{HT})$ systems are implicated in the modulation of mood and anxiety. Descending cortical glutamatergic neurons regulate 5-HT neuronal activity in the midbrain raphe nuclei through $\alpha$-amino-3-hydroxy-5-methyl-4isoxazolepropionic acid (AMPA) and N-methyl-D-aspartate (NMDA) receptors. To analyze the functional role of GLUAI-containing AMPA receptors in serotonergic neurons, we used the Cre-ERT2/loxP-system for the conditional inactivation of the GLUAI-encoding Grial gene selectively in 5-HT neurons of adult mice. These Gria ${ }^{5-H T-1-}$ mice exhibited a distinct anxiety phenotype but showed no alterations in locomotion, depression-like behavior, or learning and memory. Increased anxiety-related behavior was associated with significant decreases in tryptophan hydroxylase $2(\mathrm{TPH} 2)$ expression and activity, and subsequent reductions in tissue levels of 5-HT, its metabolite 5-hydroxyindoleacetic acid (5-HIAA), and norepinephrine in the raphe nuclei. However, TPH2 expression and activity as well as monoamine levels were unchanged in the projection areas of 5-HT neurons. Extracellular electrophysiological recordings of 5-HT neurons revealed that, while $\alpha$ I-adrenoceptor-mediated excitation was unchanged, excitatory responses to AMPA were enhanced and the 5-HT IA autoreceptor-mediated inhibitory response to 5-HT was attenuated in Gria ${ }^{5-H T-1-}$ mice. Our data show that a loss of GLUAI protein in 5-HT neurons enhances AMPA receptor function and leads to multiple local molecular and neurochemical changes in the raphe nuclei that dysregulate 5-HT neuronal activity and induce anxiety-like behavior.

Neuropsychopharmacology (20I5) 40, I47I-|484; doi: I0.1038/npp.2014.332; published online 2 I January 2015
\end{abstract}

\section{INTRODUCTION}

In the central nervous system (CNS), serotonin (5-HT) is exclusively synthesized by serotonergic neurons originating in the raphe nuclei. The dorsal and median raphe nuclei of the midbrain give rise to ascending projections that, due to their widespread distribution and extensive connectivity, are involved in many physiological processes underlying cognition, emotions, and perception (Cools et al, 2008; Heninger, 1997). These include the control of many complex behaviors such as aggression, impulsive behavior,

\footnotetext{
*Correspondence: Dr T Weber, AHG Klinik Wilhelmsheim, 7I570 Oppenweiler, Germany. Tel: +49 07193 52215, Fax: +49 07193 52245, E-mail: tweber@ahg.de

${ }^{8}$ These authors contributed equally to this work

Received 10 March 2014; revised 12 December 2014; accepted 15 December 2014; accepted article preview online 30 December 2014
}

decision making, responsiveness to punishment and aversive signaling or anxiety (Carver and Miller, 2006; Cools et al, 2008; Dayan and Huys, 2009; Lucki, 1998; Rogers, 2011). Accordingly, serotonergic dysregulation during development and/or adulthood has been associated with many psychiatric disorders with diverse psychopathology (Carver and Miller, 2006; Finger et al, 2007; Geyer and Vollenweider, 2008; Gordon and Hen, 2004; Mann, 2003; Pardo and Eberhart, 2007; Zill et al, 2004).

5 -HT neurons in the midbrain raphe nuclei receive modulatory inputs from glutamatergic neurons (Jacobs and Azmitia, 1992), which influence 5-HT neuronal firing and 5-HT release both locally as well as in distant target brain areas (Celada et al, 2002; Tao and Auerbach, 2000). The principal receptor for fast glutamate-mediated signal transmission is the AMPA receptor. In the raphe nuclei, it has been shown that activation of AMPA receptors on 5-HT neurons leads to increased firing in these neurons and 
increased 5-HT release (Gartside et al, 2007; Levine and Jacobs, 1992). Four subunits of the AMPA receptor, GLUA1A4, contribute to the formation of different cell-typedependent heterotetrameric receptors (Dingledine et al, 1999). Within this family, the function of the GLUA1containing AMPA receptor appears to be unique. Thus, as demonstrated in hippocampal CA1 pyramidal cells, GLUA1containing AMPA receptors are not critically involved in synaptic signal transmission, but they constitute a pool of extrasynaptic AMPA receptors that is necessary for activityinduced increases in synaptic transmission (Jensen et al, 2003; Zamanillo et al, 1999). Global GLUA1-deficient mice exhibit impairments in many different forms of learning and memory (for review see (Sanderson et al, 2008) as well as alterations in depressive and anxiety-like behaviors (Bannerman et al, 2004; Chourbaji et al, 2008c; Fitzgerald et al, 2010; Vekovischeva et al, 2004). Given the involvement of 5-HT in mood and anxiety, we hypothesised that these latter effects of the global Grial deletion involve changes in 5-HT function.

To examine the role of GLUA1 subunit containing AMPA receptors in serotonergic neurons, we generated 5-HT neuron-specific GLUA1-deficient mice $\left(\right.$ Gria $\left.^{5 \mathrm{HT}-1-}\right)$. To exclude developmental adaptations and indirect effects, we used the transgenic CreERT2/loxP-system that allows inducible deletion of the loxP-flanked Grial gene (encoding GLUA1) selectively in 5-HT neurons in adult mice $\left(\right.$ Grial $\left.^{5-\mathrm{HT}-I^{-}}\right)$. Using behavioral, neurochemical, molecular, and electrophysiological assays, we identified a distinct anxiety phenotype in Gria $1^{5-\mathrm{HT}-1-}$ mice that most likely involves altered serotonergic signaling and dysregulation of 5 -HT neuronal firing.

\section{MATERIALS AND METHODS}

\section{Generation of Transgenic Gria $1^{5-\mathrm{HT}-1-}$ Mice}

All experiments were approved by German animal welfare authorities (Regierungspräsidium Karlsruhe). We used an inducible 5-HT neuron-specific CreERT2-driver

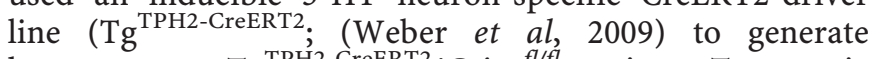

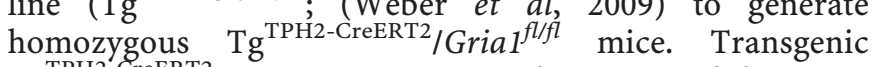
$\mathrm{Tg}^{\mathrm{TPH} 2-\mathrm{CreERT} 2}$ mice were previously generated by DNA microinjection into the pronucleus of $\mathrm{C} 57 \mathrm{BL} / 6 \mathrm{~N}$ mouse oocytes, and transgenic offspring were always maintained on a C57BL/6N background. Grial ${ }^{\mathrm{fl} / \mathrm{fl}}$ mice were generated by homologous recombination in R1 embryonic stem cells (Zamanillo et al, 1999) that were injected in C57BL6/N blastocysts. Grial ${ }^{\mathrm{f} / \mathrm{fl}}$ mice are available from Jackson laboratories (B6N.129-Grial ${ }^{\text {tm2Rsp/J }}$ ). Grial ${ }^{\mathrm{f} / \mathrm{fl}}$ mice were backcrossed on a C57BL/6N background to attain fully congenic C57BL/6N Grial $1^{\mathrm{fl} / \mathrm{fl}}$ mice before matings started with $\mathrm{Tg}^{\mathrm{TPH} 2-\mathrm{CreERT} 2}$ mice.

To generate 5-HT neuron-specific Grial-knockout mice (Gria1 $1^{5-\mathrm{HT}-1-}$ ), adult (9-12 weeks), $\mathrm{Tg}^{\mathrm{TPH} 2-\mathrm{CreERT}} /$ Grial $^{\mathrm{fl} / \mathrm{fl}}$ mice were injected twice daily for five consecutive days with $1 \mathrm{mg}(100 \mu \mathrm{l})$ of tamoxifen i.p. (Sigma) (dissolved in a vehicle of corn oil/ethanol $(10: 1)$ ). This tamoxifen induction protocol has previously shown superior recombination rates (Leone et al, 2003; Mori et al, 2006) and showed highly efficient recombination when used with $\mathrm{Tg}^{\mathrm{TPH} 2-\mathrm{CreERT} 2}$ mice
(Weber et al, 2009). Grial ${ }^{\mathrm{fl} / \mathrm{fl}}$ littermates receiving tamoxifen as above served as the control group.

\section{PCR-Based Detection of Raphe Nuclei-Specific Grial Gene Deletion}

Four weeks after tamoxifen treatment, brains were dissected and snap-frozen. Brain region-specific tissue punches of the dorsal raphe nucleus (DRN) and the cerebellum were cut on a cryostat (Leica). The following primers were used to detect the 250-bp fragment of the non-recombined loxP-flanked Exon 11 of Grial: MH60 (5'-CACTCACAGCAATGAA GCAGGAC- $\left.3^{\prime}\right)$ and 3int ${ }^{\prime}$ (5'-CTGCCTGGGTAAAGT GACTTGG-3 ${ }^{\prime}$ ). The primers 1005 (5'-AATGCCTAGTACTAT AGTGCACG-3') and 3int $3^{\prime}$ detect both the non-recombined loxP-flanked exon 11 of Grial at $1500 \mathrm{bp}$ and the recombined deleted exon 11 at $250 \mathrm{bp}$. All PCR reactions were performed as follows: $94{ }^{\circ} \mathrm{C}$ denaturation for $4 \mathrm{~min} ; 35$ cycles of $94^{\circ} \mathrm{C}$ denaturation for $30 \mathrm{~s}, 60^{\circ} \mathrm{C}$ annealing for $30 \mathrm{~s}$, $72{ }^{\circ} \mathrm{C}$ elongation for $30 \mathrm{~s}$ and finally $72{ }^{\circ} \mathrm{C}$ elongation for $4 \mathrm{~min}$.

\section{Immunohistochemical Detection of 5-HT Neuron-Specific Loss of GLUA1 Protein}

Immunohistochemistry (IHC) was carried out using duallabel immunofluorescence as previously described (Aguado et al, 2013). In brief, after perfusion and postfixation with $4 \%$ PFA at $4{ }^{\circ} \mathrm{C}, 60 \mu \mathrm{m}$ coronal sections were cut on a vibratome (Leica V1000). The following antibodies were used for IHC: rabbit anti-TPH2 (Dianova; $1: 1000$ ) mouse antiGLUA1 (NeuroMab; $1: 400$ ). Secondary antibodies were goat anti-rabbit Alexa-488 (Life Technologies; $1: 1000$ ) and goat anti-mouse Alexa-498 (Life Technologies; 1:1000). Fluorescent signals were examined using a confocal laser-scanning microscope (Zeiss LSM 710). Images of slices showing staining for THP2 were acquired. The ratio of GLUA1 - I $\mathrm{TPH} 2+$ neurons to all TPH2 + neurons was calculated separately for median and dorsal raphe nuclei in Gria $\mathrm{f}^{\mathrm{fl} / \mathrm{fl}}$ $(n=3)$ and Grial $1^{5-\mathrm{HT}-1-}(n=3)$ mice.

\section{Neurochemistry}

Concentrations of monoamines and their metabolites as well as TPH2 and Tyrosine Hydroxylase (TH) activity were determined in Grial ${ }^{1 / \mathrm{fl}}$ and Grial ${ }^{5-\mathrm{HT}-1-}$ mice 4 weeks after tamoxifen treatment (Berger et al, 2012) (see Supplementary Methods for details). Using punching needles, brain region-specific tissue samples punches were acquired from brain slices $(200 \mu \mathrm{m})$ cut on a cryostat (Leica). For determination of the rate of TPH2 and TH activity, mice were injected with the $\mathrm{L}$-aromatic amino acid decarboxylase inhibitor NSD 1015 (m-hydroxybenzyl-hydrazine; $100 \mathrm{mg} / \mathrm{kg}$ i.p.) $30 \mathrm{~min}$ before brain dissection. Accumulation of the serotonin and dopamine precursor molecules 5-hydroxytryptophan (5-HTP) and dihydroxyphenylalanine (L-DOPA) was determined.

\section{TPH2 Western Blot}

SDS-PAGE and immunoblot analyses with TPH2 antibodies (Dianova) were performed as described previously (Lau 
et al, 2010). Brains for quantitative immunoblot analysis were snap-frozen, and brain region-specific homogenates (midbrain raphe nuclei, hippocampus, prefrontal cortex) were prepared from Grial $1^{\mathrm{fl} / \mathrm{fl}}$ and Grial ${ }^{5-\mathrm{HT}-1-}$ mice. IRdye conjugated secondary antibodies were detected using the Odysses CLx imaging system (Li-Cor Biosciences). Macro-based quantification of TPH2 signals was performed using the ImageJ software (NIH). TPH2-dependent fluorescence intensities (A.U.) were measured as intensity/area covered by immuoreactive bands. For each brain region, lysates of five animals were immunoblotted.

\section{Extracellular Electrophysiology}

Grial $^{\mathrm{fl} / \mathrm{fl}}$ and Grial ${ }^{5-\mathrm{HT}-I_{-}}$mice aged 14-16 weeks were taken from the home cage and briefly anesthetized with Isoflurane and killed by cervical dislocation. Coronal slices ( $300 \mu \mathrm{m}$ thick) containing the DRN were prepared, and recordings of the firing activity of presumed 5-HT neurons in the continuous presence of the $\alpha 1$-adrenoceptor agonist phenylephrine $(\mathrm{PE}, 3 \mu \mathrm{M})$ were made using glass microelectrodes as described previously (Ayissi Mbomo et al, 2012). Multiple units encountered during multiple electrode tracks through the DRN were recorded. The waveform signal was recorded at $10 \mathrm{KHz}$ using Spike2 (version 4.02) (CED) and stored for off-line analysis. Isolated units were tested with 2min pulses of 5 -HT $(50 \mu \mathrm{M})$ and AMPA (1 and $3 \mu \mathrm{M})$. All drug solutions were made up in aCSF containing PE $(3 \mu \mathrm{M})$.

Offline, spikes were converted to events in Spike2 (CED) or Offline sorter (Plexon) using thresholding and/or template matching (Spike2) or principal component analysis (Offline sorter). The basal firing rate (in the presence of $\mathrm{PE}$ ) was determined in a 2-min period at the start of the recording: the waveform average and interspike interval histogram were also examined in this period. To quantify drug responses, firing rates were determined during the $2 \mathrm{~min}$ baseline before each drug and in a period of $2 \mathrm{~min}$ following drug application, covering the maximum change from the baseline. Responses to 5-HT are quoted as \% inhibition (reduction in firing rate during 5-HT perfusion as a percentage of the baseline rate) and responses to AMPA are quoted as extra spikes (i.e., number of spikes above baseline firing during the $2 \mathrm{~min}$ drug response).

\section{8-OH-DPAT-Induced Hypothermia}

The hypothermic response to $5-\mathrm{HT}_{1 \mathrm{~A}}$ receptor activation was assessed in Grial ${ }^{\mathrm{f} / \mathrm{fl}}$ and Gria $1^{5-\mathrm{HT}-/-}$ mice. Mice were singly housed in clean cages for $10 \mathrm{~min}$ and three baseline rectal temperature measurements were then taken at $15 \mathrm{~min}$ intervals. Immediately after the third baseline measurement, animals received 8-hydroxy-2-(di-n-propylamino)tetralin (8-OH-DPAT; Sigma) intraperitoneally $(0.5 \mathrm{mg} / \mathrm{kg})$ and body temperature was monitored every $15 \mathrm{~min}$ for a total of $90 \mathrm{~min}$. The dose of $0.5 \mathrm{mg} / \mathrm{kg} 8-\mathrm{OH}-\mathrm{DPAT}$ has previously been shown to produce a robust, but submaximal, hypothermic response in mice thus excluding the possibility of a ceiling effect (Goodwin et al, 1985a).

\section{Behavioral Experiments}

Behavioral experiments were conducted at least 4 weeks after the last tamoxifen injection (Vogt et al, 2008). Male mice were single-housed in a reversed dark-light cycle and were supplied with food and water ad libitum. All experiments were performed during the dark cycle. Animals were subjected to tests of locomotion, exploration, anxiety, depression, and learning and memory. To avoid interference between the different tests, three clusters of tests were used: one cohort was subjected to Novel Cage Test, Open field and Novel Object Exploration, Dark-Light-Box, Hotplate Test, Tail Suspension Test, Porsolt Forced Swim Test and Learned Helplessness Paradigm, a second cohort performed Open field and Novel Object Exploration, Hotplate Test, Fear Conditioning and Morris Water Maze; and a third cohort was assigned to Novel Cage Test, Open field and Novel Object Exploration, Elevated O-Maze, DarkLight-Box and Conditioned Taste Aversion. An additional cohort was assigned to the tail-flick test. Animals were randomly assigned to one cohort, resulting in animal numbers of 10-14 animals per genotype per cohort. To reduce the confounding effects of previous test situations potentially interfering with subsequent behavioral testing, we applied a test order from less to more stressful tests (Chourbaji et al, 2008a; McIlwain et al, 2001) and assessed the behavior with a minimum interval of $48 \mathrm{~h}$ between different tests, with longer intervals up to 14 days after more stressful, exhausting or aversive tests (eg, Porsolt Forced Swim Test, Fear Conditioning).

\section{Open Field and Novel Object Exploration}

As previously described (Hellweg et al, 2007), activity monitoring was conducted in a square, white, open field, measuring $50 \times 50 \mathrm{~cm}^{2}$ and illuminated from above with dim red light. Data were analyzed using the image processing system EthoVision 3.0 (Noldus Information Technology, Wageningen, The Netherlands). Parameters assessed were distance moved, velocity, and time in center. After $10 \mathrm{~min}$, a novel object was introduced into the middle of the arena. Object exploration was assessed for $10 \mathrm{~min}$, recording the latency of first approach, as well as the total number of approaches (Grial ${ }^{\mathrm{ft} / \mathrm{fl}}: n=37$; Gria1 $1^{5-\mathrm{HT}-I-}: n=37$ ).

\section{Novel Cage}

Animals were placed into a novel environment (macrolon cage type II) with a thin layer of bedding, as described previously (Chourbaji et al, 2006). Rearings were counted for $300 \mathrm{~s}$ (Grial ${ }^{\mathrm{fl} / \mathrm{fl}}: n=25 ;$ Grial $\left.^{5-\mathrm{HT}-l-}: n=24\right)$.

\section{Dark-Light Box}

The Dark-Light Box consisted of a dark and a 600 lux illuminated plastic chamber, connected by a tunnel as described previously (Fuss et al, 2010). Mice were placed into the dark compartment and latency to first exit, number of exits, and total time in the light compartment were recorded for $5 \min \left(\right.$ Grial $\left.^{\mathrm{fl} / \mathrm{fl}}: n=25 ; G r i a 1^{5-\mathrm{HT}-l-}: n=24\right)$.

\section{Elevated O-Maze}

The maze consists of a gray plastic annular runway (width $6 \mathrm{~cm}$, outer diameter $46 \mathrm{~cm}, 50 \mathrm{~cm}$ above ground level) with two opposing $90^{\circ}$ sectors protected by walls (height $10 \mathrm{~cm}$ ). 
As previously described (Fuss et al, 2010), animals were placed in one of the protected sectors and observed for $5 \mathrm{~min}$ analyzing latency to first exit, number of exits, and total time spent in the open parts $\left(\right.$ Grial $^{\mathrm{f} / \mathrm{fl}}: n=11$; Grial $\left.1^{5-\mathrm{HT}-l-}: n=10\right)$.

\section{Porsolt Forced Swim Test}

Mice were placed into a glass cylinder $(23 \mathrm{~cm}$ height, $13 \mathrm{~cm}$ diameter) filled with water $\left(21^{\circ} \mathrm{C}\right)$ up to a height of $12 \mathrm{~cm}$, as described earlier (Chourbaji et al, 2006). During a test period of $6 \mathrm{~min}$, onset of immobility and percentage of time spent immobile were determined using EthoVision 3.0 $\left(\right.$ Grial $^{\mathrm{fl} / \mathrm{fl}}: n=14 ;$ Grial $\left.^{5-\mathrm{HT}-l-}: n=13\right)$.

\section{Tail Suspension Test}

As previously described (Chourbaji et al, 2006), mice were suspended by their tails with adhesive tape attached to a hook, which was coupled to a computer-assisted energy meter (Bioseb, Chaville, France). A test session lasted $6 \mathrm{~min}$, during which the time spent immobile and the latency to become immobile were determined (Gria ${ }^{\mathrm{fl} / \mathrm{fl}}: \quad n=14$; Grial $\left.^{5-\mathrm{HT}-l-}: n=13\right)$.

\section{Learned Helplessness}

The learned helplessness paradigm is a depression model in which an animal is exposed to unpredictable and uncontrollable stressors (Chourbaji et al, 2006; Chourbaji et al, 2005). See Supplementary Methods for a detailed description of the experimental procedure.

\section{Fear Conditioning}

For contextual and cued conditioning, mice were placed into the conditioning chamber and conditioning was performed as described in detail in Supplementary Methods (Strekalova et al, 2003).

\section{Morris Water Maze}

The Morris Water Maze is a test for spatial reference memory, in which the animals have to find an escape platform hidden under the surface of opaque water in a circular pool (von Bohlen und Halbach et al, 2006) (see Supplementary Methods for details).

\section{Conditioned Taste Aversion}

Conditioned taste aversion (CTA) is a form of classical conditioning, in which mice associate drinking saccharin (conditioned stimulus-CS) with a subsequent unpleasant sensation, that is, nausea (unconditioned stimulus-US) induced by lithium chloride (LiCl) (Balschun et al, 2003; see Supplementary Methods for details).

\section{Hotplate Test}

Mice were tested on the Hotplate (ATLab, Vendargues, France) set at $53^{\circ} \mathrm{C}\left(+/-0.3^{\circ} \mathrm{C}\right)$ for $45 \mathrm{~s}$ (Chourbaji et al, 2008b). Latency to first reaction, that is, licking hind paws or jumping, was assessed $\left(\right.$ Grial $^{\mathrm{fl} / \mathrm{fl}}: n=26 ;$ Grial $^{5-\mathrm{HT}-I^{-}}$: $n=26)$.

\section{Tail-flick Test}

The tail-flick reflex was evoked by a heat stimulus applied via an infrared light source at the underside of the tail in unrestrained mice kept in Plexiglas enclosures (Tappe-Theodor et al, 2007; see Supplementary Methods for details).

\section{Statistical Analysis}

Statistical analyses were performed using SigmaPlot 11.0, GraphPad Prism 5 or SPSS 20. Inter-group comparisons were made by Student's $t$-tests or Mann-Whitney $U$-test. Where appropriate, the model was complemented by within subject factors to explore the time-dependence of genotype effects. The parameters of the probe trial of the Morris Water Maze were assessed using a two-way mixed model ANOVA with genotype as between-factor and place as within-factor. Electrophysiological responses to AMPA were analyzed by two-way ANOVA on ranks with genotype and AMPA concentration as the two factors. Significance for all tests was set at $p<0.05$. Data are presented as mean \pm standard error (SEM) or median \pm interquartile range (IQR).

\section{RESULTS}

\section{Evidence of 5-HT Neuron-Specific Grial Gene Deletion in Adult Grial ${ }^{5-\mathrm{HT}-l-}$ Mice}

PCR on the samples from dorsal raphe was used to confirm recombination of the loxP-flanked exon 11 of the GLUA1 encoding gene Grial in tamoxifen-treated Gria $1^{5-\mathrm{HT}-I_{-}^{-}}$mice (Supplementary Results and Supplementary Figure S1). Upon verification of raphe nuclei-specific Grial recombination, we used double-fluorescence IHC to assess 5-HT neuron-specific recombination efficacy in tamoxifen-treated Grial $1^{\mathrm{f} / \mathrm{fl}}$ and Grial $^{5-\mathrm{HT}-1-}$ mice (Figure 1). TPH2 antibodies were used to define serotonergic neurons. In Grial ${ }^{5-\mathrm{HT}-1-}$ mice, GLUA1 was only present in $13.1 \%$ (SEM: \pm 0.92 ) of TPH2 + neurons, whereas in Grial $^{\mathrm{f} / \mathrm{fl} l}$ controls $90.2 \%$ (SEM: \pm 0.43 ) of TPH $2+$ 5-HT neurons also exhibited GLUA1 staining indicating highly efficient Grial deletion in 5-HT neurons of Gria1 ${ }^{5-}$ HT- $I-$ mice (Supplementary Table S1). No differences in recombination efficacy were found between dorsal (mean: 12.9\% TPH2 + /GLUA1 + neurons, SEM: \pm 1.8 ) and median raphe nuclei (mean: $13.1 \%$ TPH $2+/$ GLUA1 + neurons, SEM: \pm 0.99$)$ in Grial $1^{5-\mathrm{HT}-1-}$ mice.

\section{Learning and Memory is Unaltered in Grial ${ }^{5-\mathrm{HT}-l-}$ Mice}

In the Morris Water Maze (Supplementary Table S2), both Grial $^{\mathrm{tl} / \mathrm{fl}}$ and Gria1 $1^{5-\mathrm{HT}-1-}$ mice showed decreasing search times and decreasing path length over the 24 training trials (latency: $\mathrm{F}_{11,253}=8.8, p<0.001$; path: $\mathrm{F}_{11,253}=32.1, p<0.001$; velocity: $\left.\mathrm{F}_{11,253}=1.645, p=0.087\right)$. Although Grial ${ }^{5-\mathrm{HT}-1-}$ mice had comparable latencies (genotype: ns), there was a trend for reduced distances to reach the platform compared with controls $\left(\mathrm{F}_{1,23}=4.2, p=0.053\right)$, an effect that was not 

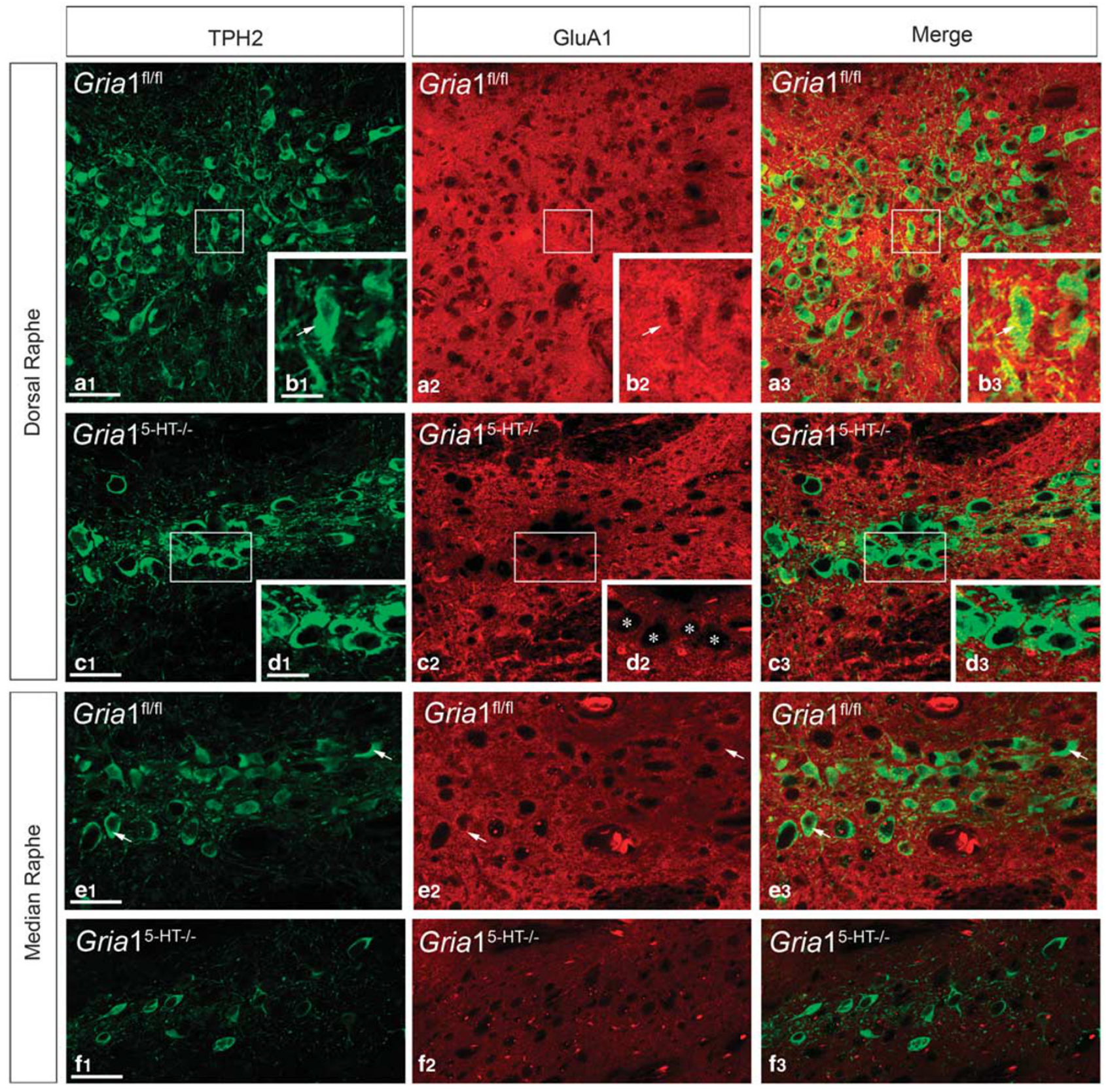

Figure I Immunohistochemical verification of 5-HT neuron-specific GLUAI loss. Brains of Gria I ${ }^{5-H T-I-}$ and Gria I ${ }^{\text {fl/ }}$ mice were removed 4 weeks after tamoxifen administration. Double-fluorescent IHC with TPH2- (green) and GLUAI-antibodies (red) was performed, as shown in color-separated images and in the corresponding overlay $(\mathrm{a} 3-\mathrm{f} 3)$ in the dorsal $(\mathrm{al}-\mathrm{d} 3)$ and median (el-f3) raphe nucleus. White boxes indicate the tissue areas enlarged in the insets. (al-b3, el-e3) In Gria I fl/fl mice, most immunopositive cells for TPH2 in both the median and dorsal raphe nucleus co-expressed GLUAI. Labeling for $\mathrm{TPH} 2$ was distributed in cell bodies and dendrites, while labeling for GLUAI was mostly restricted to the neuropil but also found in the cytoplasm of neurons (f.i. white arrows in bl-b3 and el-e3). (cl-d3, fl-f3) In Gria $\left.\right|^{5-H T-1-}$ mice, most TPH2-immunopositive cells in both the median and dorsal raphe nucleus were immunonegative for GLUAI. Labeling for TPH2 was distributed in cell bodies and dendrites, while labeling for GLUAI was absent from cell bodies (f.i. white asterisks in d2) and only detectable in the neuropil. Scale bar: a, c, e, f: $100 \mu \mathrm{m}$; b, d: $50 \mu \mathrm{m}$.

caused by higher swim speed (genotype: ns). In the probe trial on day 5, both Grial $1^{\mathrm{fl} / \mathrm{fl}}$ and Gria1 ${ }^{5-\mathrm{HT}-1-}$ mice displayed a significant preference for the target quadrant $\left(\mathrm{F}_{1,22}=7.6, p=0.011\right)$ as well as an increased number of crossings over the previous platform position $\left(\mathrm{F}_{1,22}=15.4\right.$, $p=0.001)$. Again, Gria $1^{5-\mathrm{HT}}-I_{-}$mice did not differ from controls in reference memory performance as shown by nonsignificant genotype and interaction effects.
Similarly, in fear conditioning, Gria $1^{5-\mathrm{HT}-1-}$ mice displayed comparable memory retention in both context and cued version of the test (Supplementary Table S2).

In the conditioned taste aversion test, there was no significant difference in saccharin preference between the sessions conducted $48 \mathrm{~h}$ and 14 days after the conditioning session, and Grial $1^{5-\mathrm{HT}-1-}$ mice did not differ from controls at either time point (Supplementary Table S2). 
Altered nociception was excluded as a confounding factor as Grial ${ }^{\mathrm{l} / \mathrm{fl}}$ and Grial $1^{5-\mathrm{HT}-1-}$ mice did not behave differently on the hotplate and tail-flick test (Supplementary Table S2).

\section{Gria1 ${ }^{5-\mathrm{HT}-I-}$ Mice Display Unaltered Depressive-Like Behavior}

In the Tail Suspension Test, latency to become immobile and total immobility times were consistent across the two consecutive test days and $\mathrm{Grial}^{5-\mathrm{HT}-1-}$ mice did not differ from control mice (Figure $2 \mathrm{a}$ and $\mathrm{b}$ ).

In the Porsolt Forced Swim Test, both genotypes showed reduced latency to become immobile $\left(\mathrm{F}_{1,25}=67.7, p<0.001\right.$; Figure $2 \mathrm{c})$ and reduced total immobility time $\left(\mathrm{F}_{1,25}=13.6\right.$, $p=0.001$; Figure $2 \mathrm{~d}$ ) on the second compared with the first day. Gria $1^{5-\mathrm{HT}-1-}$ mice did not differ from control mice in terms of latency or total immobility time.

In the Learned Helplessness Paradigm, there was no difference in escape latency or number of failures between Grial $1^{\mathrm{fl} / \mathrm{fl}}$ and Gria $1^{5-\mathrm{HT}-/-}$ mice (Figure 2e and f).

\section{Distinct Anxiety Phenotype in Grial $1^{5-\mathrm{HT}-I-}$ Mice}

In the Novel Cage Test, Grial ${ }^{5-\mathrm{HT}-1-}$ mice made $20 \%$ fewer rearings than controls ( $p=0.027$; Figure $3 \mathrm{a})$.

In the Open Field Test, Gria1 $1^{5-\mathrm{HT}-1-}$ mice behaved similarly to controls with respect to locomotion (distance moved, velocity) and spatial activity patterns (time in center, mean distance to walls). During the habituation phase, there were significant time-dependent effects (distance moved: $\mathrm{F}_{1,72}=178.8, p<0.001$; velocity: $\mathrm{F}_{1,72}=171.8$, $p<0.001$; distance to walls: $\mathrm{F}_{1,72}=206.3, p<0.001$; center time: $F_{1,72}=169.2, p<0.001$ ) but no significant differences between genotypes. However, when a novel object was introduced, Gria $1^{5-\mathrm{HT}-1-}$ mice showed increased latency to approach the novel object ( $p=0.014$; Figure $3 \mathrm{~b}$ ) and a nonsignificant trend toward a decrease in the number of approaches compared with controls ( $p=0.062$; Figure $3 c$ ).

In the Elevated O-Maze, Grial ${ }^{5-\mathrm{HT}-I_{-}}$mice demonstrated a distinct anxiety-like phenotype with increased latency to enter the anxiety-related unsheltered parts $(p=0.030$; Figure $3 \mathrm{~d})$ and decreased number of entries into the unsheltered parts $(p=0.008$; Figure $3 \mathrm{e})$. Grial ${ }^{5-\mathrm{HT}-1-}$ mice also spent less time in the unsheltered parts of the maze ( $p=0.004$; Figure 3f).

In the Dark-Light Box, Gria1 ${ }^{5-\mathrm{HT}-1-}$ mice displayed a similar pattern of anxiety-like behavior with decreased numbers of exits from the dark compartment $(p<0.001$; Figure $3 \mathrm{~h})$ and decreased time spent in the light compartment $(p=0.019 ;$ Figure 3i). The latency to enter the anxiety-related light compartment also showed a non-significant trend toward an increase in Grial ${ }^{5-\mathrm{HT}-I-}$ mice $(p=0.065$; Figure $3 \mathrm{~g})$.

\section{Reduced TPH2 Activity and Expression in the Raphe Nuclei of GRIA $1^{5-\mathrm{HT}-{ }_{-}}$Mice}

TPH2 catalyzes the initial and rate-limiting step of 5-HT synthesis from tryptophan to 5-HTP. In Gria1 $1^{5-\mathrm{HT}-1-}$ mice, the accumulation of 5-HTP after administration of NSD 1015 was significantly lower $(45 \%)$ than in controls in the midbrain raphe nuclei $(p<0.001)$ but was unchanged in the projection areas of 5-HT neurons in the hippocampus, striatum, and prefrontal cortex (Table 1). In the same animals and brain regions, the accumulation of the dopamine precursor L-DOPA, reflecting the activity of tyrosine hydroxylase, did not differ between genotypes. In immunoblots of midbrain raphe lysates, we found that TPH2 protein expression was significantly reduced by $14 \%$ in Grial ${ }^{5-\mathrm{HT}-1-}$ mice compared with controls $(p<0.05$; Figure $4 \mathrm{a}$ and $\mathrm{b}$ ). Similar to 5-HTP accumulation, TPH2 expression in the projection areas of 5-HT neurons was not decreased.

\section{Reduced Serotonin and Norepinephrine Tissue Levels in} the Midbrain Raphe Nuclei of Gria $1^{5-\mathrm{HT}-I-}$ Mice

Consistent with the reduced TPH2 expression and 5-HTP accumulation in the midbrain of Grial ${ }^{5-\mathrm{HT}-1-}$ mice, tissue levels of 5 -HT were reduced by $41 \%$ relative to controls $(p=0.006)$, while levels of the 5-HT metabolite 5-HIAA were decreased by $33 \%(p=0.029)$ (Table 1$)$. In this region, we also found that tissue levels of NE were reduced by $40 \%$ in Grial ${ }^{5-\mathrm{HT}-l-}$ mice relative to controls $(p=0.002)$. In contrast, in the projection areas of 5-HT neurons, levels of 5-HT and NE, and their metabolites, did not differ between Grial $^{\mathrm{fl} / \mathrm{fl}}$ and Grial $1^{5-\mathrm{HT}-I-}$ mice.

\section{Enhanced AMPA Receptor Mediated Excitation And Attenuated 5- $\mathrm{HT}_{1 \mathrm{~A}}$ Autoreceptor-Mediated Inhibition in DRN 5-HT Neurons}

Extracellular recordings were made from 73 neurons in the dorsal raphe nuclei of slices from six Grial $1^{\mathrm{f} / \mathrm{fl}}$ and six Gria1 ${ }^{5-\mathrm{HT}-1-}$ mice (2-8 neurons per animal). All neurons had broad, biphasic (negative/positive), or triphasic (positive/negative/positive) waveforms (Figure $5 \mathrm{a}$ and $\mathrm{b}$ ) and fired regularly. After examination of the distribution of basal firing rates, five outliers (three from Grial $1^{5-\mathrm{HT}-I_{-}}$ mice and two from Grial ${ }^{\mathrm{f} / \mathrm{fl}}$ mice) with basal firing rates above $10 \mathrm{~Hz}$ were excluded from further analysis. For the remaining cells, there was no difference between groups in the basal firing rate (Median (IQR) 1.78 (1.13-3.88 (34) Grial $^{\mathrm{l} / \mathrm{fl}}$ vs 2.24 (1.38-3.64 (34) Grial $1^{5-\mathrm{HT}-I_{-}}$; MannWhitney $U$-test) (Figure $5 \mathrm{c}$ ). In the majority of neurons, firing was partially inhibited by application of 5-HT $(50 \mu \mathrm{M}, 2 \mathrm{~min})$ (Figure $5 \mathrm{a}$ and $\mathrm{b})$. The inhibitory effect of 5 -HT was significantly smaller in the Gria $1^{5-\mathrm{HT}-1-}$ group than in the control group (percentage inhibition: $50.6 \pm 6.16 \%$ (31) Grial ${ }^{\mathrm{fl} / \mathrm{fl}}$ vs $23.7 \pm 5.6$ (33) Grial ${ }^{5-\mathrm{HT}-l_{-}}$; $t$ test $p<0.05$; Figure $5 \mathrm{~d}$ ). AMPA ( 1 and $3 \mu \mathrm{M}, 2 \mathrm{~min}$ ) evoked short-lived, concentration-dependent increases in firing rate in all neurons tested (Figure $5 \mathrm{a}$ and $\mathrm{b}$ ). The excitatory effect of AMPA was significantly greater in the Grial $1^{5 \mathrm{HT}-I-}$ group than in the control group (Figure 5e). Thus, two-way ANOVA on ranks revealed a significant main effect of AMPA concentration $\left(\mathrm{F}_{1,115}=54.1, p<0.001\right)$ and a significant main effect of genotype $\left(F_{1,115}=9.9, p=0.002\right)$; there was no significant interaction.

\section{5- $\mathrm{HT}_{1 \mathrm{~A}}$-Autoreceptor-Mediated Hypothermia is Unaffected}

Injection of the $5-\mathrm{HT}_{1 \mathrm{~A}}$ autoreceptor agonist 8-OH-DPAT elicited a hypothermic response over the following $90 \mathrm{~min}$ 
Tail Suspension Test
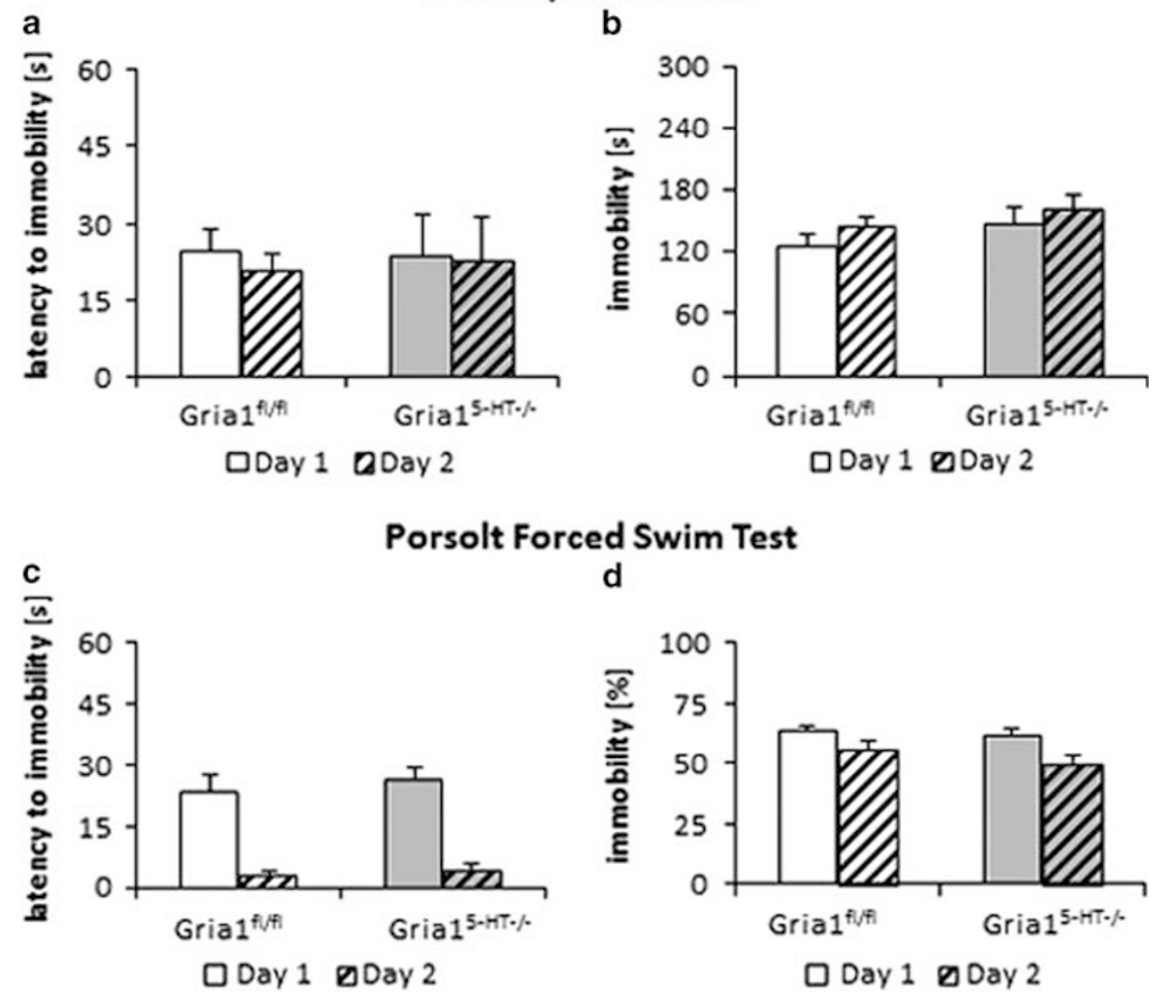

Learned Helplessness Paradigm
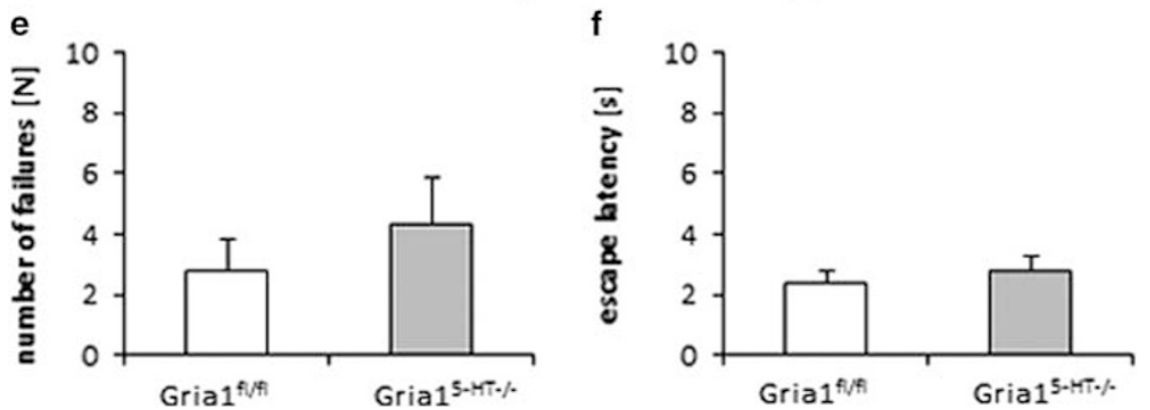

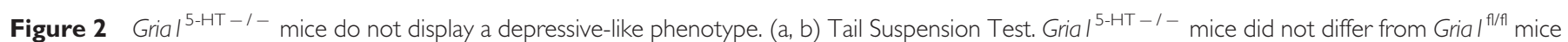
in (a) latencies to immobility and (b) time spent immobile (s) on the first and the second day of the test. (c, d) Porsolt Forced Swim Test. Gria I-HT - I- mice did not differ from Grial ${ }^{\mathrm{fl} / \mathrm{fl}}$ mice in (c) latencies to immobility and (d) \% time immobile on the first and the second day of the test. (e, f) Learned Helplessness Paradigm. Gria $1^{5-H T-1-}$ mice did not differ from Gria ${ }^{f / f l}$ mice in $(\mathrm{e})$ the number of failures and $(\mathrm{f})$ the mean escape latency. All bars represent mean \pm SEM. Grial I/fit: $n=14$; Grial $\left.\right|^{5-H T-I-}: n=13$.

$\left(\mathrm{F}_{5,65}=41.4, p<0.001 ;\right.$ Supplementary Figure S2). However, the time-course and magnitude of the response did not differ between genotypes.

\section{DISCUSSION}

Here we examined the consequences of a selective tamoxifen-induced conditional deletion of the GLUA1encoding Grial gene in 5-HT neurons of adult mice. Using PCR and immunohistochemistry, we confirmed recombination of floxed Grial alleles in the raphe nuclei and loss of GLUA1 protein in the majority of 5-HT neurons in Grial ${ }^{5-}$ $\mathrm{HT}-I_{-}$mice. Behavioral testing revealed that Grial $1^{5-\mathrm{HT}-I-}$ mice showed increased anxiety-like behavior in the Novel
Cage Exploration, Novel Object Exploration, Elevated O-Maze, and Dark-Light Box compared with controls. Biochemical measures demonstrated that Grial $1^{5-\mathrm{HT}-I-}$ mice had reduced $\mathrm{TPH} 2$ expression and activity in the raphe nuclei, and concomitant reductions in tissue levels of 5-HT and its metabolite 5-HIAA, as well as NE. In contrast, there were no differences between controls and Grial ${ }^{5-\mathrm{HT}-I-}$ mice in these biochemical measures in the projection areas of 5-HT neurons. The basal firing of 5HT neurons driven by stimulation of $\alpha_{1}$-adrenoceptors did not differ between genotypes, but the excitatory effect of AMPA on 5-HT firing was enhanced in the Grial ${ }^{5-\mathrm{HT}-I-}$ mice compared with controls. We also found that $5-\mathrm{HT}_{1 \mathrm{~A}}$ autoreceptor-mediated inhibition of 5-HT neuronal firing was attenuated in Grial $1^{5-\mathrm{HT}-I-}$ mice, but the autoreceptor- 
Novel Cage Exploration Test

a

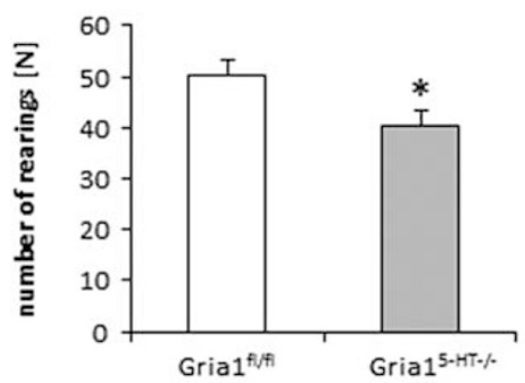

d

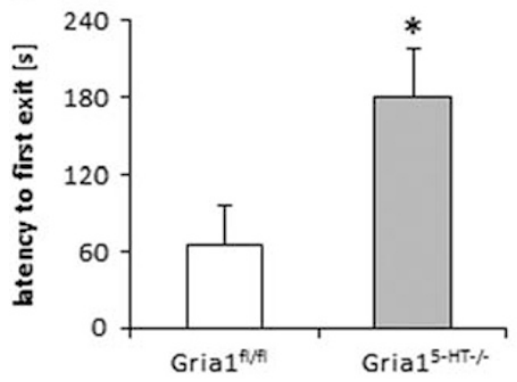

g

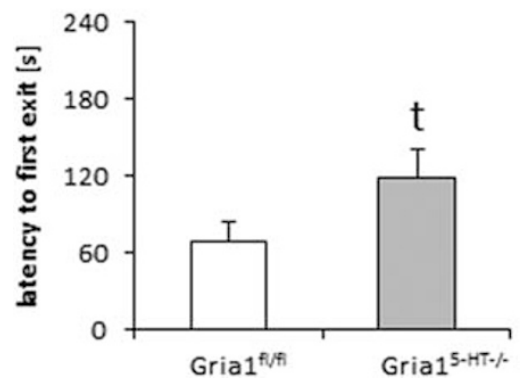

b

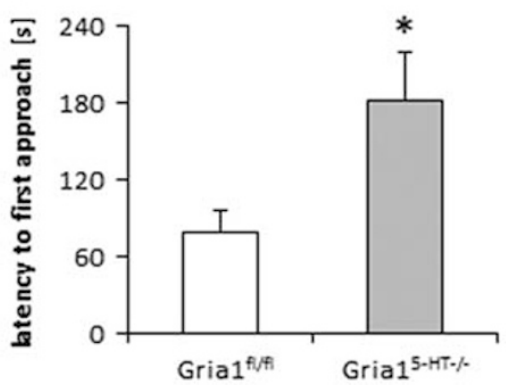

Elevated O-Maze Test

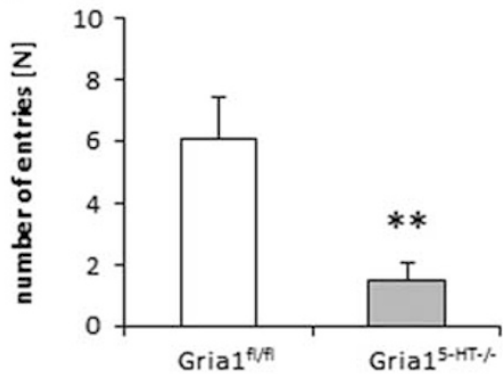

Dark-Light Box Test

h

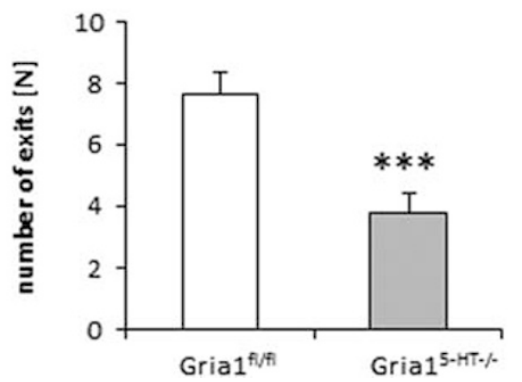

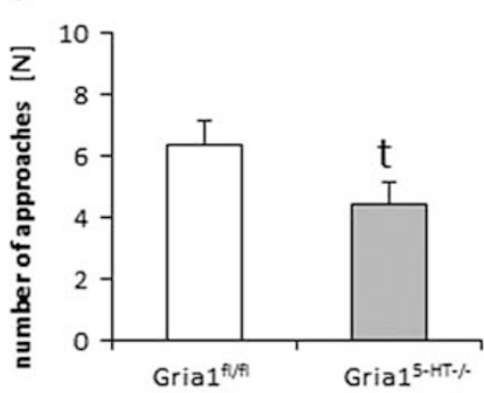

f

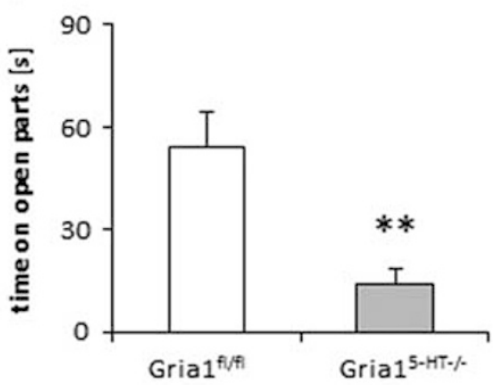

i

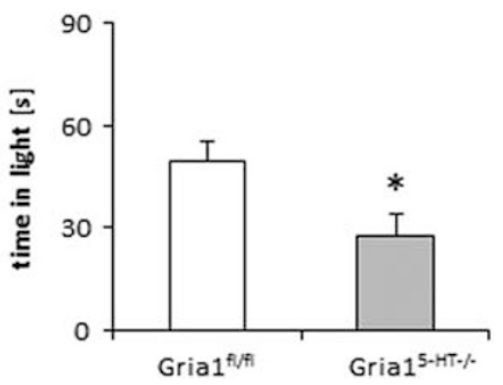

Figure 3 Grial ${ }^{5-H T-1-}$ mice exhibit an anxiety-like phenotype. (a) Novel Cage Exploration Test. Gria ${ }^{5-H T-1-}$ mice showed significantly fewer rearings (Gria I/f/f: $n=25$; Grial $\left.{ }^{5-H T-I-}: n=24\right)$. (b, c) Novel Object Exploration Test. Gria ${ }^{5-H T-I-}$ mice investigated a novel object in the open field with significantly higher latency (b). The number of approaches showed a trend toward a decrease (c; $p=0.062)\left(G r i a l^{f / f f l}: n=37 ; G r i a l^{5-H T-I-}: n=37\right)$. (d-f)

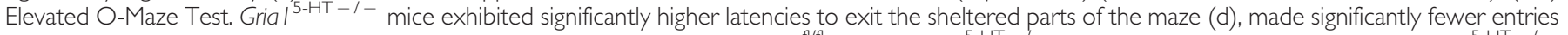

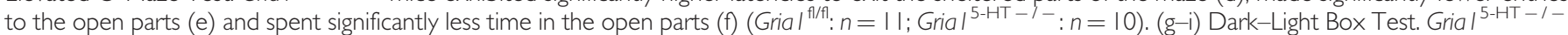
mice showed a trend toward increased latency to exit the dark compartment ( $g ; p=0.065)$, made significantly fewer exits of the dark compartment ( $h$ ) and spent significantly less time in the light compartment (i) (Grial ${ }^{\mathrm{flfl}}: n=25$; Grial $\left.{ }^{5-\mathrm{HT}-l-}: n=24\right)$. All bars represent mean \pm SEM. Student's $t$-test: $t$, trend; $* p<0.05$; $* * 0<0.01 ; * * * * 0<0.001$.

mediated hypothermic response to the $5-\mathrm{HT}_{1 \mathrm{~A}}$ agonist 8OH-DPAT was unaltered.

\section{Evidence for a Selective Loss of GLUA1}

Grial mRNA has been demonstrated in most neuronal populations of the brain including the ascending raphe nuclei (Gold et al, 1997; Sato et al, 1993), but Gria1 mRNA or GLUA1 protein expression specifically in serotonergic neurons has not, as yet, been confirmed. Here we show that in control mice GLUA1 is present in the overwhelming majority of DRN and MRN neurons, which co-label for TPH2 (and hence are presumed to be 5-HT neurons). GLUA1 was also seen in the neuropil of controls suggesting that GLUA1 is also present in non-5-HT neurons in the midbrain. In Gria1 $1^{5-\mathrm{HT}-l-}$ mice, the co-localization of TPH2 and GLUA1 was massively reduced indicating that only a small proportion of 5 -HT neurons retained GLUA1 expression.

\section{Behavioral Phenotype}

Here we found that mice lacking GLUA1 selectively in 5-HT neurons display a selective anxiety phenotype. Anxiety-like behavior was increased in a number of test paradigms, which rely on the conflict between the animals' drive to exploratory behavior and their risk avoidance. In contrast, we found no changes in tests of depressive-like behaviors 
Table I Brain-Region-Specific Monoamine and Metabolite Concentrations and in vivo 5-HT and DA Synthesis Rate

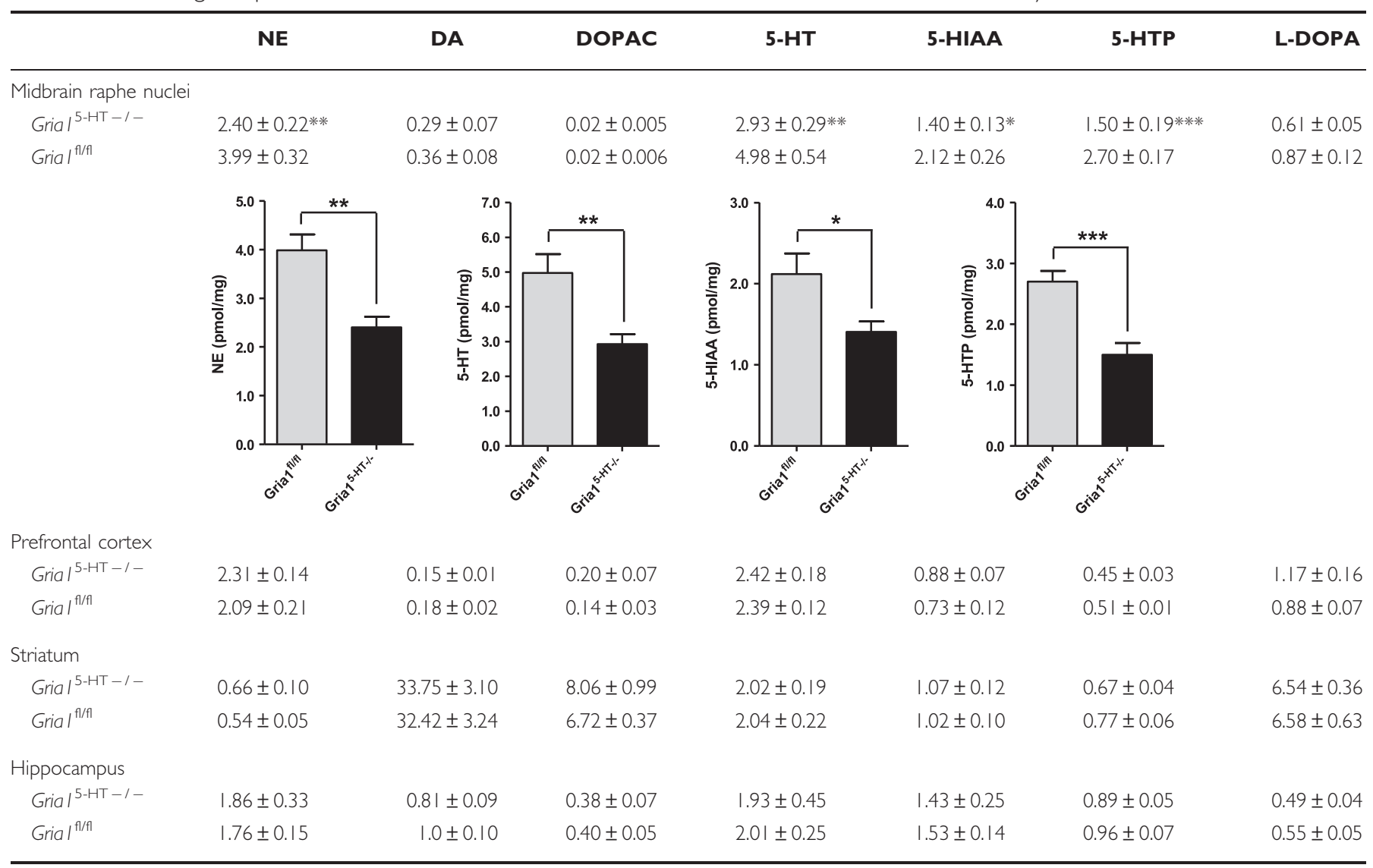

Abbreviations: DA, dopamine; DOPAC, 3,4-dihydroxyphenyl-acetic acid; L-DOPA, L-3,4-dihydroxyphenylalanine; NE, norepinephrine; 5-HIAA, 5-hydroxyindoleacetic acid; 5-HTP, 5-hydroxytryptophan; 5-HT, 5-hydroxytryptamine. Brain-region-specific tissue concentrations (pmol/mg) of NE, DA, DOPAC, 5-HT, and 5-HIAA were determined in Grial ${ }^{5-H T-I-}(N=6)$ and Grial $I^{\mathrm{f} / \mathrm{fl}}(\mathrm{N}=6)$ mice. Brain-region-specific tissue concentrations (pmol/mg) of 5-HTP and L-DOPA were determined in Gria $^{5-H T-I-}(N=7)$ and Gria ${ }^{f / f l}(N=7)$ mice that had been treated with the L-aromatic amino-acid decarboxylase inhibitor NSD I0I5 30 min before death. Genotype-based comparisons were conducted using unpaired $t$-test. $* p<0.05$; $* * * 0.0$ I; $* * * * * 0.00$ I. Data are presented as mean values \pm SEM.

(Porsolt forced swim, learned helplessness) or in measures of hippocampus-dependent (Morris water maze), amygdala-dependent (fear conditioning), and hippocampus-independent (conditioned taste aversion) learning and memory paradigms. Locomotion and nociception were also unaltered.

Mice lacking GLUA1 globally throughout their lifetime display profound impairments in spatial working memory linked to increased long-term memory for novel space (Sanderson and Bannerman, 2012; Sanderson et al, 2011). They also show mild deficits in motor coordination (Bannerman et al, 2004) and massive novelty induced hyperlocomotion (Bannerman et al, 2004; Chourbaji et al, 2008c; Vekovischeva et al, 2001). Global Gria1-knockout mice have also been shown to exhibit increased learned helplessness (Chourbaji et al, 2008c) as well as mania- and schizophrenia-related behavioral abnormalities (Barkus et al, 2012; Fitzgerald et al, 2010; Wiedholz et al, 2008). The involvement of many different GLUA1-deficient neuronal populations probably underlies the observed complex phenotype. Indeed under these circumstances, it is virtually impossible to infer the specific neuronal population responsible for any identified behavioral 'symptom'. Hence, it is not surprising that complex and conflicting results for anxiety-related behavior have also been reported in global Grial-knockouts (Barkus et al, 2012). Increased anxiety-like behavior has been shown in the hyponeophagia test (Bannerman et al, 2004), while reduced anxiety-like behavior was found in the elevated plus maze and Dark-Light Box (Fitzgerald et al, 2010; Vekovischeva et al, 2004). This apparent inconsistency could be a result of the impaired short-term habituation and novelty induced hyperlocomotion in global Gria1-knockouts that complicate analysis of anxiety behavior (Barkus et al, 2012; Chourbaji et al, 2008c; Wiedholz et al, 2008).

An explanation for the discrepancy between global and 5-HT neuron-specific Gria1 knockouts is the possibility that a lack of GLUA1 in non-5-HT neurons of global Gria1 knockouts conceals the anxiety-like behavior resulting from a loss of GLUA1 in 5-HT neurons. Alternatively, it may be that developmental adaptive mechanisms tend to offset the effects of a GLUA1 loss in 5-HT neurons. To decipher the contribution of specific neuronal populations to the Gria1knockout phenotype, other investigators have also turned to the CreERT2/loxP-system to achieve inducible and tissuespecific Gria1-deletions in adult mice (Engblom et al, 2008; Inta et al, 2013; Vogt et al, 2014). Interestingly, the selective deletion of Grial in neither dopaminergic neurons nor in 
a

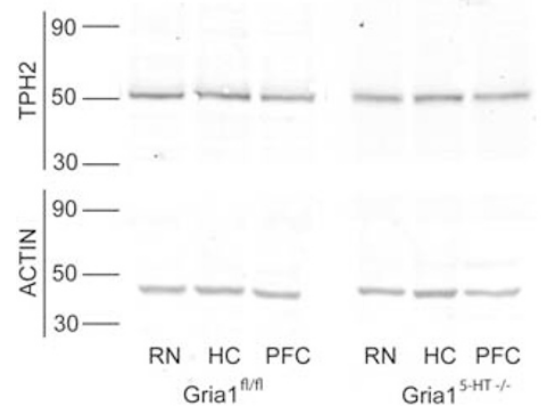

b

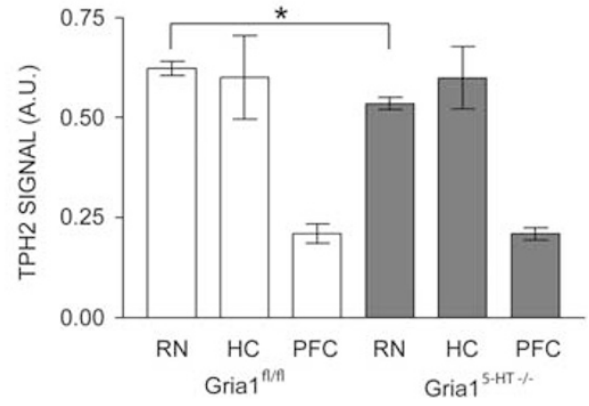

Figure 4 Selective reduction of TPH2-expression in raphe nuclei. Brains of Grial ${ }^{\mathrm{fl} / \mathrm{l}}$ and $\mathrm{Gria} \mathrm{I}^{5-\mathrm{HT}-1-}$ mice were dissected for analysis of TPH2 expression by immunoblotting. (a) Representative Western blots. TPH2 antibody stainings of lysates from midbrain raphe nuclei (RN), hippocampus (HC) and prefrontal cortex (PFC) revealed immunoreactive bands above $50 \mathrm{kDa}$. As a loading control, the same lysates were stained with actin antibodies yielding immunoreactive bands at roughly $40 \mathrm{kDa}$ with the same intensities. (b) Brain-region specific TPH2 expression. Analysis of TPH2 expression revealed a significant reduction of TPH2-dependent fluorescence in raphe lysates by $14 \%$ in Grial ${ }^{5-H T-1-}$ mice $(n=5 ; p<0.05)$. In contrast, lysates from the projection areas of 5-HT neurons (HC and PFC) did not show significant differences in fluorescence intensities between Grial ${ }^{\mathrm{flfl}}$ and Gria ${ }^{5-H T-l-}$ mice. $^{\text {. }}$

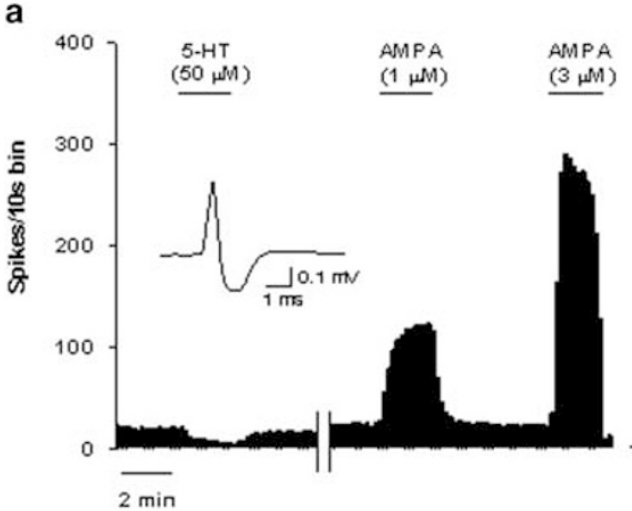

b

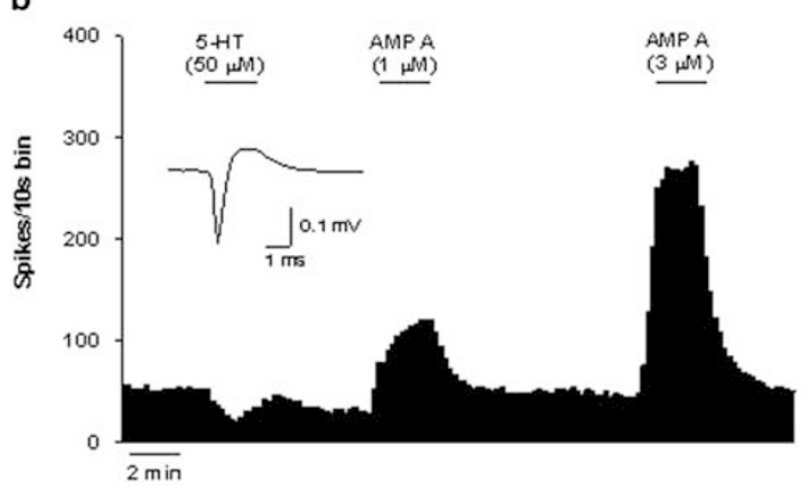

alpha1 adrenoceptor-mediated basal firing

C

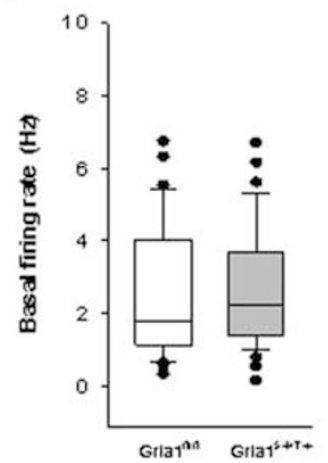

Inhibitory response to $5 \mathrm{HT}$

d

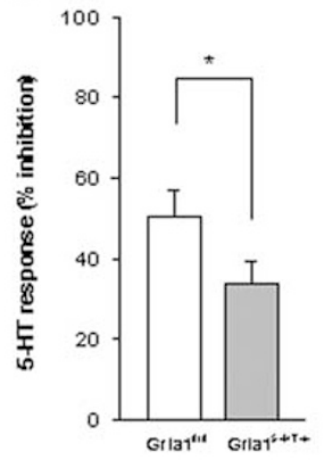

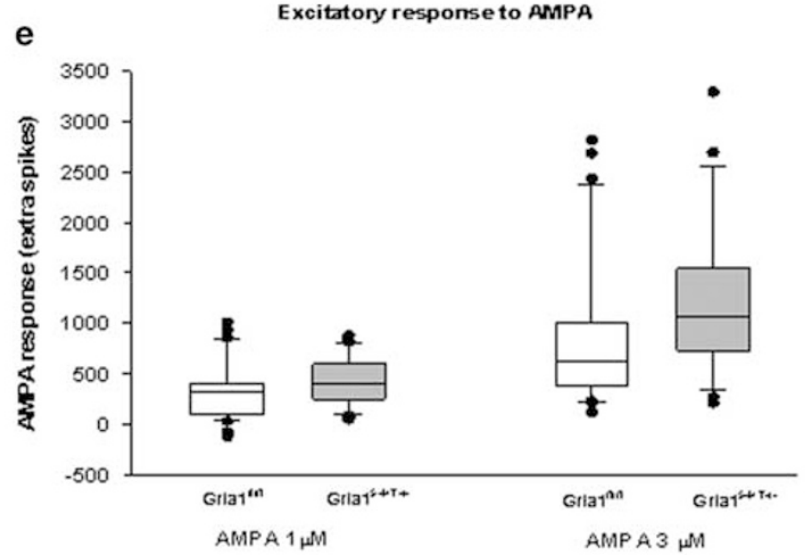

Figure 5 Presumed 5-HT neurons in the DRN of Grial ${ }^{5-H T-1-}$ mice show enhanced excitatory response to AMPA and attenuated inhibitory response to 5-HT. In vitro extracellular electrophysiological recordings were made from presumed 5-HT neurons in the DRN of Grial ${ }^{\mathrm{flfl}}$ and Grial ${ }^{5-H T-l-}$ mice. (a, b) Firing rate histograms ( $10 \mathrm{~s}$ bins) from two individual DRN 5-HT neurons showing that application of 5-HT (50 $\mu$ M) inhibits firing and application of AMPA (I and $3 \mu \mathrm{M}$ ) evokes a concentration-related increase in firing. Insets show the action potential waveforms of the two neurons: (a) a triphasic (positive/negative/ positive) waveform, (b) a biphasic (negative/positive) waveform. Both waveforms were typical of the neurons encountered in both genotypes. Periods of drug application ( $2 \mathrm{~min}$ ) are marked by black bars. (c) Analysis of group data revealed no difference between genotypes in the basal firing rate in the presence of $3 \mu \mathrm{M}$ phenylephrine (Mann-Whitney $U$-test $\left(n=32\right.$ neurons from 6 Grial ${ }^{\mathrm{fl} / \mathrm{fl}}$ mice and 30 neurons from 6 Gria $I^{5-H T-1-}$ mice)). (d) However, the response to $5-\mathrm{HT}(50 \mu \mathrm{M})$ was significantly attenuated in Gria $I^{5-H T-1-}$ mice compared with Gria I $^{\mathrm{fl} / \mathrm{fl}}$ mice $($ * $p<0.05 t$-test $(n=31$ neurons from 6

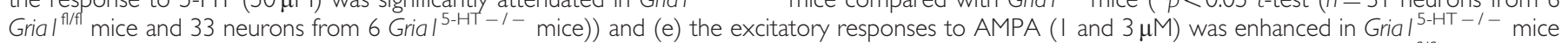
(concentration: $F_{1,115}=54.1, p<0.001$; genotype: $F_{1,115}=9.9, p=0.002$; two-way ANOVA on ranks $\left(n=32\right.$ and 30 neurons from 6 Gria I ${ }^{f / f l}$ mice $(I \mu M$ and $3 \mu \mathrm{M}$ ) and 32 and 25 neurons from 6 Gria I ${ }^{5-H T}{ }^{-}$mice $(I \mu M$ and $\left.3 \mu M)\right)$ ). Panels (c) and (e) show median with IQR (box), 90th and IOth percentiles (whiskers) and outliers (circles). Panel (d) shows mean \pm SEM. 
forebrain glutamatergic neurons leads to an anxiety phenotype (personal communication Ainhoa Bilbao; (Vogt et al, 2014)) supporting the view, that it is only a Grial-deletion in 5-HT neurons that induces an anxiety phenotype. The fact that we observed increased anxietyrelated behavior in animals with a manipulation of 5-HT neurons is not surprising as this neurotransmitter system has been implicated in the evolution of anxiety (Leonardo and Hen, 2008).

\section{Mechanisms Underlying the Behavioral Phenotype}

Activation of AMPA receptors in the DRN increases the firing rate of 5-HT neurons (Gartside et al, 2007) and increases 5-HT release both locally and in terminal regions (Tao and Auerbach, 2000). Using in vitro extracellular electrophysiology, we recorded DRN neurons with broad action potentials and regular, low frequency, firing in the presence of phenylephrine. These presumed 5-HT neurons are similar in firing rate, pattern and action potential shape to phenotypically identified 5-HT neurons (Aghajanian et al, 1983) in the rat and similar to those reported by us previously in the mouse DRN (Ayissi Mbomo et al, 2012). As we have previously observed in rat (Gartside et al, 2007) and mouse (Ayissi Mbomo et al, 2012), all presumed 5-HT neurons showed a concentration-dependent excitatory AMPA response. Our immunohistochemistry confirmed the expression of GLUA1 in virtually all DRN 5-HT neurons of control mice and showed that there was an almost complete loss of GLUA1 in 5-HT neurons of Gria1 ${ }^{5-\mathrm{HT}-1-}$ mice. The fact that the AMPA response was greater in Gria $1^{5-\mathrm{HT}-I-}$ mice strongly suggests that, in normal animals, the GLUA1 subunit is an important determinant of the AMPA response. However, the fact that, when GLUA1 is lost, AMPA sensitivity of DRN 5-HT neurons was enhanced (rather than abolished) in Grial ${ }^{5 H T-/-}$ mice suggests an upregulation of other AMPA receptor subunits or their postranscriptional splice forms and that receptors thus constructed produce a greater response for a given concentration of AMPA. In previous work we observed that AMPA receptor-mediated synaptic responses in the hippocampal CA1 pyramidal cells of global Gria1-knockout mice are preserved indicating that, for synaptic transmission, the missing GluA subunits can be substituted by other AMPA receptor subunits (Zamanillo et al, 1999). Dense expression of both Gria2 and Gria4 subunit mRNA and low Gria3 mRNA expression have been reported previously in the ascending raphe nuclei of the midbrain (Gold et al, 1997; Sato et al, 1993). Thus, we hypothesize the enhanced AMPA response observed in 5HT neurons lacking GLUA1 is mediated by receptors composed of the remaining subunits, which effectively substitute for GLUA1.

During quiet wake and in animals under anesthesia, AMPA receptors on 5-HT neurons do not appear to be tonically activated (Levine and Jacobs, 1992). However, some evidence suggests that AMPA-mediated glutamatergic tone does drive 5-HT firing during the active dark phase (Tao and Auerbach, 2000). The increase in AMPA receptor sensitivity we found in our Grial $1^{5 H T-/-}$ mice would be expected to lead to an enhancement of AMPA-driven 5-HT firing activity under such circumstances.
Here, we also determined the impact of 5-HT-specific GLUA1 depletion by measuring biochemical indices of 5-HT neuronal activity. In the midbrain of Gria1 $1^{5 H T-/-}$ mice, we found a small but significant decrease in TPH2 expression and a marked decrease in TPH2 activity as demonstrated by reduced 5-HTP accumulation. 5-HT and 5-HIAA levels were also reduced in the midbrain, most likely as a consequence of the diminished TPH2 activity in the same area. Interestingly, there were no changes in TPH2 expression and activity or 5-HT and 5-HIAA levels in terminal regions. While 5-HT synthesis in the cell bodies of 5-HT neurons supplies local 5-HT release in the midbrain, 5 -HT released in the projection areas of 5-HT neurons is synthesized in the terminals (Carkaci-Salli et al, 2011; Gutknecht et al, 2009). A dissociation of TPH2 activity in cell body and terminal regions has been reported previously (Browne et al, 2011) suggesting differential regulation of TPH2 for somatodendritic 5-HT release in the raphe nuclei or for axonal/synaptic release in the innervated brain areas.

In addition to the effect of GLUA1 deficiency on the AMPA response, we observed that the response to 5-HT was attenuated in Gria1 $1^{5 H T-/-}$ mice. This response has previously been shown to be mediated by $5-\mathrm{HT}_{1 \mathrm{~A}}$ autoreceptors (Fairchild et al, 2003; Johnson et al, 2002), suggesting Grial $1^{5 H T-/-}$ mice have reduced $5-\mathrm{HT}_{1 \mathrm{~A}}$ autoreceptor sensitivity either via receptor downregulation or desensitization. However, using the behavioral test for $5-\mathrm{HT}_{1 \mathrm{~A}}$ autoreceptor function, the 5- $\mathrm{HT}_{1 \mathrm{~A}}$ agonist 8-OHDPAT-induced hypothermia (Goodwin et al, 1985b), we found no changes in 5- $\mathrm{HT}_{1 \mathrm{~A}}$ autoreceptor sensitivity. This is in line with observations that 8-OHDPAT-induced hypothermia might be a less sensitive model of $5-\mathrm{HT}_{1 \mathrm{~A}}$ activity than inhibition of $5-\mathrm{HT}$ neuron firing (Fletcher et al, 1993; Kelai et al, 2008). The $5-\mathrm{HT}_{1 \mathrm{~A}}$ autoreceptor is thought to be an important inhibitory regulator of 5-HT firing. The reduced 5-HT synthesis in our Grial $1^{5 H T-/-}$ mice would be expected to result in reduced local release of 5-HT in the DRN. The reduction in $5-\mathrm{HT}_{1 \mathrm{~A}}$ autoreceptor sensitivity noted in the electrophysiology experiments coupled with reduced 5-HT release would be expected to result in reduced autoinhibition and hence an increased net firing rate of 5-HT neurons. Although changes in $5-\mathrm{HT}_{1 \mathrm{~A}}$ autoreceptor function during development have been associated with increased anxiety behaviors, downregulation of $5-\mathrm{HT}_{1 \mathrm{~A}}$ autoreceptors in adulthood has been shown not to impact on anxiety measures (Donaldson et al, 2013; Richardson-Jones et al, 2011). As we used an inducible system to achieve Grial deletion in adult Gria1 ${ }^{5 H T-/-}$ mice, the $5-\mathrm{HT}_{1 \mathrm{~A}}$ autoreceptor desensitization/downregulation observed occurred during adulthood making it unlikely that $5-\mathrm{HT}_{1 \mathrm{~A}}$ autoreceptor alterations are responsible for the observed anxiety phenotype.

Finally, we also examined NE levels and, surprisingly, found a significant decrease in the midbrain region, whereas NE levels were unchanged in all other brain areas examined. The $\mathrm{Tg}^{\mathrm{TPH} 2-\mathrm{CreERT} 2}$ driver line is 5-HT neuronspecific (Weber et al, 2009) and thus only deletes the Grial gene in 5-HT neurons. Hence, this raphe-regionspecific NE reduction must be an indirect effect of the GLUA1 loss in 5-HT neurons. Interestingly, mice with a homozygous Tph2 gene deletion reportedly have reduced levels of NE in the raphe nuclei (Gutknecht et al, 2012), 
suggesting that the reduction in $\mathrm{NE}$ might be an indirect consequence of the reduced TPH2 activity we observed.

$\mathrm{NE}$ acting through $\alpha_{1}$-adrenoceptors on 5-HT neurons is thought to be the major drive accounting for the pacemaker activity of 5-HT neurons in vivo in animals under anesthesia or during quiet wake (Baraban and Aghajanian, 1980; Sakai and Crochet, 2000). In our electrophysiology experiments, we found normal $\alpha_{1}$-adrenoceptor sensitivity suggesting that the observed decrease in $\mathrm{NE}$ in the raphe nuclei had not resulted in an increase in postsynaptic receptor sensitivity. The decrease in availability of $\mathrm{NE}$ in the DRN in the presence of normosensitive $\alpha_{1}$ adrenoceptors might be expected to result in reduced tonic firing of 5-HT neurons, at least during some phases of the sleep-wake cycle.

Taken together our biochemical and electrophysiological data suggest that a dysregulation of 5-HT firing underlies the behavioral anxiety-phenotype in Gria1 ${ }^{5 H T-}$ - mice. 5-HT neuron-specific Gria1 deletion in adult mice results in enhanced AMPA receptor sensitivity and reduced TPH2 activity. Reduced $5-\mathrm{HT}_{1 \mathrm{~A}}$ autoreceptor mediated inhibition and probably reduced $\alpha_{1}$-adrenoceptor-mediated tonic firing activity in 5-HT neurons are likely consequences of raphe nuclei specific reductions in 5-HT and NE. Our data suggest that Grial deletion triggers a combination of changes that alters 5-HT firing via different regulators including AMPAreceptors, $\alpha_{1}$-adrenoceptors and $5-\mathrm{HT}_{1 \mathrm{~A}}$ autoreceptors that may all have a role in the mediation of anxiety.

\section{FUNDING AND DISCLOSURE}

This work was funded by grants from the German Ministry for Education and Research (BMBF, 01GQ1003B) National Bernstein Network for Computational Neuroscience (http:// www.gesundheitsforschung-bmbf.de/en/2478.php\#Heidelberg) to D.B and P.G. and from the Deutsche Forschungsgemeinschaft (SFB636-TP3) to P.G. S.E.G was the recipient of a Royal Society International Joint Project award. R.L was supported by grants from the Spanisch Ministry of Education and Science (CONSOLIDER CSD2008-00005). The authors declare no conflict of interest.

\section{ACKNOWLEDGEMENTS}

We kindly thank Professor Rohini Kuner (University Heidelberg) for the help with measurements of the tail flick latency. We kindly thank Lena Wendler and Christiane Brandwein for their help with animal care, revitalization, perfusions, tamoxifen injections, and genotyping.

\section{REFERENCES}

Aghajanian GK, Vandermaelen CP, Andrade R (1983). Intracellular studies on the role of calcium in regulating the activity and reactivity of locus coeruleus neurons in vivo. Brain Res 273: 237-243.

Aguado C, Fernandez-Alacid L, Cabanero MJ, Yanagawa Y, Schilling K, Watanabe M et al (2013). Differential maturation of GIRK2-expressing neurons in the mouse cerebellum. J Chem Neuroanat 47: 79-89.

Ayissi Mbomo R, Gartside S, Ngo Bum E, Njikam N, Okello E, McQuade R (2012). Effect of Mimosa pudica (Linn.) extract on anxiety behaviour and GABAergic regulation of 5-HT neuronal activity in the mouse. J Psychopharmacol 26: 575-583.

Balschun D, Wolfer DP, Gass P, Mantamadiotis T, Welzl H, Schutz G et al (2003). Does cAMP response element-binding protein have a pivotal role in hippocampal synaptic plasticity and hippocampus-dependent memory? J Neurosci 23: 6304-6314.

Bannerman DM, Deacon RM, Brady S, Bruce A, Sprengel R, Seeburg PH et al (2004). A comparison of GluR-A-deficient and wild-type mice on a test battery assessing sensorimotor, affective, and cognitive behaviors. Behav Neurosci 118: 643-647.

Baraban JM, Aghajanian GK (1980). Suppression of firing activity of 5-HT neurons in the dorsal raphe by alpha-adrenoceptor antagonists. Neuropharmacology 19: 355-363.

Barkus C, Feyder M, Graybeal C, Wright T, Wiedholz L, Izquierdo A et al (2012). Do GluA1 knockout mice exhibit behavioral abnormalities relevant to the negative or cognitive symptoms of schizophrenia and schizoaffective disorder? Neuropharmacology 62: 1263-1272.

Berger SM, Weber T, Perreau-Lenz S, Vogt MA, Gartside SE, Maser-Gluth C et al (2012). A functional Tph2 C1473G polymorphism causes an anxiety phenotype via compensatory changes in the serotonergic system. Neuropsychopharmacology 37: 1986-1998.

Browne CA, Clarke G, Dinan TG, Cryan JF (2011). Differential stress-induced alterations in tryptophan hydroxylase activity and serotonin turnover in two inbred mouse strains. Neuropharmacology 60: 683-691.

Carkaci-Salli N, Salli U, Kuntz-Melcavage KL, Pennock MM, Ozgen H, Tekin I et al (2011). TPH2 in the ventral tegmental area of the male rat brain. Brain Res Bull 84: 376-380.

Carver CS, Miller CJ (2006). Relations of serotonin function to personality: current views and a key methodological issue. Psychiatry Res 144: 1-15.

Celada P, Puig MV, Martin-Ruiz R, Casanovas JM, Artigas F (2002). Control of the serotonergic system by the medial prefrontal cortex: potential role in the etiology of PTSD and depressive disorders. Neurotox Res 4: 409-419.

Chourbaji S, Brandwein C, Vogt MA, Dormann C, Gass P (2008a). Evaluation of effects of previous exposure to an acute stressor before testing for depression-like behaviours in mice. Stress 11: $170-175$.

Chourbaji S, Brandwein C, Vogt MA, Dormann C, Hellweg R, Gass $P$ (2008b). Nature vs. nurture: can enrichment rescue the behavioural phenotype of BDNF heterozygous mice? Behav Brain Res 192: 254-258.

Chourbaji S, Urani A, Inta I, Sanchis-Segura C, Brandwein C, Zink $M$ et al (2006). IL-6 knockout mice exhibit resistance to stress-induced development of depression-like behaviors Neurobiol Dis 23: 587-594.

Chourbaji S, Vogt MA, Fumagalli F, Sohr R, Frasca A, Brandwein C et al (2008c). AMPA receptor subunit 1 (GluR-A) knockout mice model the glutamate hypothesis of depression. FASEB J 22: 3129-3134.

Chourbaji S, Zacher C, Sanchis-Segura C, Dormann C, Vollmayr B, Gass P (2005). Learned helplessness: validity and reliability of depressive-like states in mice. Brain Res Brain Res Protoc 16: 70-78.

Cools R, Roberts AC, Robbins TW (2008). Serotoninergic regulation of emotional and behavioural control processes. Trends Cogn Sci 12: 31-40.

Dayan P, Huys QJ (2009). Serotonin in affective control. Annu Rev Neurosci 32: 95-126.

Dingledine R, Borges K, Bowie D, Traynelis SF (1999). The glutamate receptor ion channels. Pharmacol Rev 51: 7-61.

Donaldson ZR, Piel DA, Santos TL, Richardson-Jones J, Leonardo ED, Beck SG et al (2013). Developmental effects of serotonin 1A autoreceptors on anxiety and social behavior. Neuropsychopharmacology 39: 291-302. 
Engblom D, Bilbao A, Sanchis-Segura C, Dahan L, Perreau-Lenz S, Balland B et al (2008). Glutamate receptors on dopamine neurons control the persistence of cocaine seeking. Neuron 59: 497-508.

Fairchild G, Leitch MM, Ingram CD (2003). Acute and chronic effects of corticosterone on 5-HT1A receptor-mediated autoinhibition in the rat dorsal raphe nucleus. Neuropharmacology 45: 925-934.

Finger EC, Marsh AA, Buzas B, Kamel N, Rhodes R, Vythilingham M et al (2007). The impact of tryptophan depletion and 5-HTTLPR genotype on passive avoidance and response reversal instrumental learning tasks. Neuropsychopharmacology 32: 206-215.

Fitzgerald PJ, Barkus C, Feyder M, Wiedholz LM, Chen YC, Karlsson RM et al (2010). Does gene deletion of AMPA GluA1 phenocopy features of schizoaffective disorder? Neurobiol Dis 40: $608-621$

Fletcher A, Bill DJ, Bill SJ, Cliffe IA, Dover GM, Forster EA et al (1993). WAY100135: a novel, selective antagonist at presynaptic and postsynaptic 5-HT1A receptors. Eur J Pharmacol 237: 283-291.

Fuss J, Ben Abdallah NM, Hensley FW, Weber KJ, Hellweg R, Gass P (2010). Deletion of running-induced hippocampal neurogenesis by irradiation prevents development of an anxious phenotype in mice. Plos one 5:e12769.

Gartside SE, Cole AJ, Williams AP, McQuade R, Judge SJ (2007). AMPA and NMDA receptor regulation of firing activity in 5-HT neurons of the dorsal and median raphe nuclei. Eur J Neurosci 25: 3001-3008.

Geyer MA, Vollenweider FX (2008). Serotonin research: contributions to understanding psychoses. Trends Pharmacol Sci 29: 445-453.

Gold SJ, Ambros-Ingerson J, Horowitz JR, Lynch G, Gall CM (1997). Stoichiometries of AMPA receptor subunit mRNAs in rat brain fall into discrete categories. J Comp Neurol 385: 491-502.

Goodwin GM, De Souza RJ, Green AR (1985a). The pharmacology of the hypothermic response in mice to 8-hydroxy-2(di-n-propylamino)tetralin (8-OH-DPAT). A model of presynaptic 5-HT1 function. Neuropharmacology 24: 1187-1194.

Goodwin GM, De Souza RJ, Green AR (1985b). Presynaptic serotonin receptor-mediated response in mice attenuated by antidepressant drugs and electroconvulsive shock. Nature 317: 531-533.

Gordon JA, Hen R (2004). Genetic approaches to the study of anxiety. Annu Rev Neurosci 27: 193-222.

Gutknecht L, Araragi N, Merker S, Waider J, Sommerlandt FM, Mlinar B et al (2012). Impacts of brain serotonin deficiency following Tph2 inactivation on development and raphe neuron serotonergic specification. PLoS ONE 7: e43157.

Gutknecht L, Kriegebaum C, Waider J, Schmitt A, Lesch KP (2009). Spatio-temporal expression of tryptophan hydroxylase isoforms in murine and human brain: convergent data from Tph2 knockout mice. Eur Neuropsychopharmacol 19: 266-282.

Hellweg R, Zueger M, Fink K, Hortnagl H, Gass P (2007). Olfactory bulbectomy in mice leads to increased BDNF levels and decreased serotonin turnover in depression-related brain areas. Neurobiol Dis 25: 1-7.

Heninger GR (1997). Serotonin, sex, and psychiatric illness. Proc Natl Acad Sci USA 94: 4823-4824.

Inta D, Vogt MA, Elkin H, Weber T, Lima-Ojeda JM, Schneider M et al (2013). Phenotype of mice with inducible ablation of GluA1 AMPA receptors during late adolescence: relevance for mental disorders. Hippocampus 24: 424-435.

Jacobs BL, Azmitia EC (1992). Structure and function of the brain serotonin system. Physiol Rev 72: 165-229.

Jensen V, Kaiser KM, Borchardt T, Adelmann G, Rozov A, Burnashev $\mathrm{N}$ et al (2003). A juvenile form of postsynaptic hippocampal long-term potentiation in mice deficient for the AMPA receptor subunit GluR-A. J Physiol 553: 843-856.
Johnson DA, Gartside SE, Ingram CD (2002). 5- $\mathrm{HT}_{1 \mathrm{~A}}$ receptormediated autoinhibition does not function at physiological firing rates: evidence from in vitro electrophysiological studies in the rat dorsal raphe nucleus. Neuropharmacology 43: 959-965.

Kelai S, Renoir T, Chouchana L, Saurini F, Hanoun N, Hamon M et al (2008). Chronic voluntary ethanol intake hypersensitizes 5-HT(1A) autoreceptors in C57BL/6J mice. J Neurochem 107: $1660-1670$

Lau T, Schneidt T, Heimann F, Gundelfinger ED, Schloss P (2010). Somatodendritic serotonin release and re-uptake in mouse embryonic stem cell-derived serotonergic neurons. Neurochem Int 57: 969-978.

Leonardo ED, Hen R (2008). Anxiety as a developmental disorder. Neuropsychopharmacology 33: 134-140.

Leone DP, Genoud S, Atanasoski S, Grausenburger R, Berger P, Metzger D et al (2003). Tamoxifen-inducible glia-specific Cre mice for somatic mutagenesis in oligodendrocytes and Schwann cells. Mol Cell Neurosci 22: 430-440.

Levine ES, Jacobs BL (1992). Neurochemical afferents controlling the activity of serotonergic neurons in the dorsal raphe nucleus: microiontophoretic studies in the awake cat. J Neurosci 12: 4037-4044.

Lucki I (1998). The spectrum of behaviors influenced by serotonin. Biol Psychiatry 44: 151-162.

Mann JJ (2003). Neurobiology of suicidal behaviour. Nat Rev Neurosci 4: 819-828.

McIlwain KL, Merriweather MY, Yuva-Paylor LA, Paylor R (2001). The use of behavioral test batteries: effects of training history. Physiol Behav 73: 705-717.

Mori T, Tanaka K, Buffo A, Wurst W, Kuhn R, Gotz M (2006). Inducible gene deletion in astroglia and radial glia-a valuable tool for functional and lineage analysis. Glia 54: 21-34.

Pardo CA, Eberhart CG (2007). The neurobiology of autism. Brain Pathol 17: 434-447.

Richardson-Jones JW, Craige CP, Nguyen TH, Kung HF, Gardier AM, Dranovsky A et al (2011). Serotonin-1A autoreceptors are necessary and sufficient for the normal formation of circuits underlying innate anxiety. J Neurosci 31: 6008-6018.

Rogers RD (2011). The roles of dopamine and serotonin in decision making: evidence from pharmacological experiments in humans. Neuropsychopharmacology 36: 114-132.

Sakai K, Crochet S (2000). Serotonergic dorsal raphe neurons cease firing by disfacilitation during paradoxical sleep. Neuroreport 11: 3237-3241.

Sanderson DJ, Bannerman DM (2012). The role of habituation in hippocampus-dependent spatial working memory tasks: evidence from GluA1 AMPA receptor subunit knockout mice. Hippocampus 22: 981-994.

Sanderson DJ, Good MA, Seeburg PH, Sprengel R, Rawlins JN, Bannerman DM (2008). The role of the GluR-A (GluR1) AMPA receptor subunit in learning and memory. Prog Brain Res 169: 159-178.

Sanderson DJ, Hindley E, Smeaton E, Denny N, Taylor A, Barkus C et al (2011). Deletion of the GluA1 AMPA receptor subunit impairs recency-dependent object recognition memory. Learn Mem 18: 181-190.

Sato K, Kiyama H, Tohyama M (1993). The differential expression patterns of messenger RNAs encoding non-N-methyl-D-aspartate glutamate receptor subunits (GluR1-4) in the rat brain. Neuroscience 52: 515-539.

Strekalova T, Zorner B, Zacher C, Sadovska G, Herdegen T, Gass P (2003). Memory retrieval after contextual fear conditioning induces c-Fos and JunB expression in CA1 hippocampus. Genes Brain Behav 2: 3-10.

Tao R, Auerbach SB (2000). Regulation of serotonin release by GABA and excitatory amino acids. J Psychopharmacol 14: 100-113. 
Tappe-Theodor A, Agarwal N, Katona I, Rubino T, Martini L, Swiercz J et al (2007). A molecular basis of analgesic tolerance to cannabinoids. J Neurosci 27: 4165-4177.

Vekovischeva OY, Aitta-Aho T, Echenko O, Kankaanpaa A, Seppala T, Honkanen A et al (2004). Reduced aggression in AMPA-type glutamate receptor GluR-A subunit-deficient mice. Genes Brain Behav 3: 253-265.

Vekovischeva OY, Zamanillo D, Echenko O, Seppala T, Uusi-Oukari $\mathrm{M}$, Honkanen A et al (2001). Morphine-induced dependence and sensitization are altered in mice deficient in AMPA-type glutamate receptor-A subunits. J Neurosci 21: 4451-4459.

Vogt MA, Chourbaji S, Brandwein C, Dormann C, Sprengel R, Gass P (2008). Suitability of tamoxifen-induced mutagenesis for behavioral phenotyping. Exp Neurol 211: 25-33.

Vogt MA, Elkin H, Pfeiffer N, Sprengel R, Gass P, Inta D (2014). Impact of adolescent GluA1 AMPA receptor ablation in forebrain excitatory neurons on behavioural correlates of mood disorders. Eur Arch Psychiatry Clin Neurosci 264: 625-629. von Bohlen und Halbach O, Zacher C, Gass P, Unsicker K (2006). Age-related alterations in hippocampal spines and deficiencies in spatial memory in mice. J Neurosci Res 83: 525-531.

Weber T, Bohm G, Hermann E, Schutz G, Schonig K, Bartsch D (2009). Inducible gene manipulations in serotonergic neurons. Front Mol Neurosci 2: 24.

Wiedholz LM, Owens WA, Horton RE, Feyder M, Karlsson RM, Hefner K et al (2008). Mice lacking the AMPA GluR1 receptor exhibit striatal hyperdopaminergia and 'schizophrenia-related' behaviors. Mol Psychiatry 13: 631-640.

Zamanillo D, Sprengel R, Hvalby O, Jensen V, Burnashev N, Rozov A et al (1999). Importance of AMPA receptors for hippocampal synaptic plasticity but not for spatial learning. Science 284: 1805-1811.

Zill P, Baghai TC, Zwanzger P, Schule C, Eser D, Rupprecht R et al (2004). SNP and haplotype analysis of a novel tryptophan hydroxylase isoform (TPH2) gene provide evidence for association with major depression. Mol Psychiatry 9: 1030-1036.

Supplementary Information accompanies the paper on the Neuropsychopharmacology website (http://www.nature.com/npp) 